\title{
FALASIFA
}

Al-Islam Dan Kemuhammadiyahan (Aik) Dalam Pandangan Mahasiswa UMM

\section{AL-ISLAM DAN KEMUHAMMADIYAHAN (AIK) DALAM PANDANGAN MAHASISWA UNIVERSITAS MUHAMMADIYAH MALANG (UMM)}

\author{
Faridi \\ Universitas Muhammadiyah Malang \\ Email: faridi@umm.ac.id
}

\begin{abstract}
There are three reasons for al-Islam and Kemuhammadiyahan (AIK) to be used as courses at Muhammadiyah Higher Education, including: so that students are able to become Indonesians who are Muslim and have a modern mindset; students can be touched by their souls and able to practice their values; and fostering student ethics in the midst of the Muhammadiyah Higher Education environment. However, when AIK came into contact with students who had various religious ideological backgrounds, it gave birth to various perceptions. Based on this reality, the focus of this research is formulated in the form of a question: how are students' responses and perceptions to the AIK course system? This research is descriptive analytical with data collection techniques in the form of interviews and open-ended questionnaires. This research concluded that all respondents agreed that AIK was used as a subject for reasons, among others: it was able to understand Muhammadiyah's struggle; and he is able to have a strong Islamic provision, knowledge and understanding of pure Islam, and can practice Islamic values in real life. However, AIK learning is considered too monotonous which emphasizes cognitive aspects, so that AIK does not encourage the awakening of daily values; learning methods, facilities and infrastructure also need improvement so that students avoid burnout.
\end{abstract}

Keywords: religion, Islam, students

Ada tiga alasan al-Islam dan Kemuhammadiyahan (AIK) dijadikan mata kuliah di Perguruan Tinggi Muhammadiyah, antara lain: agar mahasiswa mampu menjadi bangsa Indonesia yang beragama Islam dan mempunyai alam pikiran modern; mahasiswa dapat tersentuh jiwanya serta mampu mengamalkan nilai-nilainya; dan menumbuhkan etika kemahasiswaan di tengah-tengah lingkungan Perguruan Tinggi Muhammadiyah. Namun, ketika AIK bersentuhan dengan mahasiswa yang mempunyai latar ideologi keagamaan yang beragam melahirkan berbagai persepsi. Berdasarkan realitas tersebut, fokus riset ini dirumuskan dalam bentuk pertanyaan: bagaimana respon dan persepsi mahasiswa terhadap sistem mata kuliah AIK? Riset ini bersifat deskriptif analitis dengan teknik pengumpulan data berupa wawancara dan angket yang sifatnya terbuka. Riset ini menyimpulkan, semua responden menyetujui AIK dijadikan mata kuliah dengan alasan, antara lain: bisa untuk memahami perjuangan Muhammadiyah; dan ia mampu memiliki bekal keislaman yang kuat, pengetahuan dan pemahaman tentang Islam yang murni, serta dapat mengamalkan nilai-nilai Islam dalam kehidupan yang sebenarnya. Namun pembelajaran AIK dinilai terlalu monoton yang menekankan pada aspek kognitif, sehingga AIK kurang mendorong terbangunnya penjiwaan nilai nilai keseharian; metode pembelajaran, 
sarana maupun prasarana juga perlu pembenahan agar mahasiswa terhindar dari kejenuhan.

Kata Kunci: agama, Islam, mahasiswa

Ruang lingkup gerakan Muhammadiyah setidaknya dapat dikelompokkan menjadi tiga, antara lain: bidang keagamaan; bidang pendidikan; dan bidang kemasyarakatan. Dalam bidang keagamaan, Muhammadiyah konsisten untuk mengembalikan ajaran Islam (baca tauhid) sesuai dengan petunjuk al-Qur'an dan asSunnah As-Shahihah. Bersih dari gejela kemusyrikan, bid'ah, khurafat. Demikian pula halnya dalam ibadah, usaha untuk meluruskan ibadah, Muhammadiyah telah melakukan langkah-langkah antara lain penentuan arah kiblat di mana umumnya masyarakat menjalankan shalat menghadap ke Barat, menggunakan perhitungan astronomi (hisab) dalam menentukan awal dan akhir puasa, menyelenggarakan shalat idul fitri atau idul adha di lapangan, mengadakan kepanitiaan dalam pengumpulan dan pembagian zakat atau qurban, penyampaian khotbah dengan bahasa Indonsia, penyederhanaan upacara kelahiran, khitanan, perkawinan dan pemakaman, menghilangkan kebiasaan ziarah ke makam orang suci (wali), membershkan anggapan adanya berkah yang dimiliki kiai (ulama'), pengunaan kerudung untuk wanita serta pemisahan laki-laki dan perempuan dalam acara keagamaan.

Dalam bidang pendidikan, Muhammadiyah juga konsisten mencetak elit muslim terdidik dengan cara mendirikan lembaga pendidikan formal dari semua tingkatan. Ada beberapa tipe pendidikan (formal) Muhammadiyah, yakni: tipe Muallimin/Muallimat Yogyakarta, tipe madrasah (Ibtidaiyyah, Tsanawiyah dan Aliyah), tipe sekolah (TK, SD, SMP, SMA/Kejuruan, Universiyas, STIT dan Akademi), tipe Madrasah Diniyah. Ini berarti secara tentatif Muhammadiyah telah memainkan peran penting dalam mencerdaskan kehidupan bangsa. Karenanya, secara kuantitatif Muhammadiyah telah berhasil menjadi mitra pemerintah dalam pelaksanaan program pemerataan pendidikan.

Sedang dalam bidang kemasyarakatan Muhammadiyah mendayagunakan modal yang berasal dari zakat, imfaq, shadaqah ke dalam bentuk usaha-usaha permanen agar beban sosial masyarakat dapat terkurangi. Modal-modal tersebut dialokasikan untuk mendirikan lembaga sosial, seperti Pertolongan Kesengsaraan Umum (PKU), pendirian rumah yatim, rumah sakit/klinik dan juga lembaga pendidikan.

Jelasnya, persepsi dan misi pendidikan Muhammadiyah -dalam Muktamar Muhammadiyah di Yogyakarta tahun 1959- Abdul Kahar Muzakkir menawarkan beberapa pokok pikiran pengembangan pendidikan Muhammadiyah. Pokok pikiran itu didasarkan atas persoalan bahwa sesunggnya pendidikan tidak dapat dipisahkan dari kepentingan Muhammadiyah terhadap tujuan hidup manusia itu sendiri. Dalam kaitan itu manusia perlu ditinjau dari fungsionalnya sebagai makhluk Allah, sebagai anggota keluarga, anggota masyarakat, warga negara dan dalam hubungannya dengan alam sekitar. Sebagai makhluk Allah, manusia secara fungsional memiliki kewajiban mengabdi kepada-Nya, sebagai anggota keluarga manusia mampu memimpin dan 


\section{Faridi}

membimbing ke arah jalan yang benar, sebagai warga negara manusia harus mampu menjadi warga negara yang baik sesuai dengan tuntunan Islam, dalam hubungan dengan alam manusia harus mampu menguasai alam untuk kemaslahatan manusiasecara keselurhan (Arifin, 1990:272).

Prioritas utama yang ingin dicapai dalam pendidikan Muhammadiyah bisa difokuskan pada: jiwa tauhid yang murni; beribadah hanya kepada Allah; berbakti kepada orang tua serta bersikap baik terhadap kerabat; memiliki akhlaq yang mulia; berpengetahuan luas serta memiliki kecakapan; berguna bagi masyarakat, bangsa dan agama (Arifin, 1990:272). Untuk mewujudkan hal ini, maka setiap lembaga pendidikan Muhammadiyah diwajibkan memasukkan uliah Al-Islam dan Kemuhammadiyahan selanjutnya ditulis AIK- sebagai mata kuliah yang terintegral dari kulikulum. Harapannya agar ia dapat mempengaruhi karakter para peserta didik baik selama proses pendidikan berlangsung terlebih setelah mereka keluar/lulus.

Selain harapan tersebut, sejatinya ada tiga alasan mata kuliah AIK perlu diajarkan, yaitu: untuk membentuk mahasiswa menjadi bangsa Indonesia yang beragama Islam dan mempunyai alam pikiran modern; agar mahasiswa dapat tersentuh dan sekaligus mengamalkan ajaran Islam; dan agar mahasiswa memiliki etika dilingkungan Perguruan Tinggi Muhammadiyah. Akan tetapi, fakta menunjukkan bahwa mahasiswa yang menempuh pendidikan di Lembaga Pendidikan Muhammadiyah sangat beragam, baik aspek ideologi keagamaan maupun latar belakang agama. Dengan diwajibkannya mengambil mata kuliah AIK muncul berbagai respon mahasiswa terhadapnya; dan kerangka inilah yang dijadikan titik fokus riset ini.

\section{Fokus dan Metode Riset}

Berdasarkan latar dan fokus riset, maka problematika dalam riset ini bisa dirumuskan dengan bentuk pertanyaan, yaitu: Bagaimana persepsi mahasiswa terhadap substansi dan metode pembalajaran mata kuliah AIK? Dari pertanyaan riset ini, maka teknik pengumpulan data menggunakan wawancara dan angket yang sifatnya terbuka. Wawancara dilakukan tanpa struktur, namun tetap mengarah pada pokok persoalan; sedangkan angket terbuka semata-mata untuk memberi kesempatan kepada mahasiswa mengekspresikan pandangan dirinya substansi dan sistem pembelajaran mata kuliah AIK.

Oleh karenanya, riset ini bersifat deskriptif analitis yang fokus pada kondisi empirik sesuai dengan pandangan masing-masing mahasiswa. Penerapan metode analisis kualitatif lebih memungkinkan mengingat data yang diperoleh adalah data yang bersifat kualitatif. Selain itu analisis kualitatif merupakan suatu upaya untuk dapat menggambarkan suatu situasi atau fenomena, pokok-pokok persoalan dengan mudah dapat dipilah-pilah sesuai dengan katagori masing-masing sehingga dapat melahirkan satu kesimpulan. 


\section{Kurikulum dan Pendidikan Kemuhammadiyahan}

Dalam pandangan tradisional, kurikulum merupakan alat pembelajaran yang sangat menentukan berlangsung tidaknya proses pembelajaran. Bahkan kurikulum juga menentukan berhasil tidaknya tujuan pendidikan. Menurut Ali (1992), sesungguhnya kurikulum merupakan rencana yang menjadi panduan dalam menyelenggarakan proses pendidikan. Ia juga menjadi pemandu yang bisa mengarahkan arah mahasiswa, proses yang dilakukan dan hasilnya dinilai. Memang semula kurikulum didefinisikan sebagai sejumlah mata pelajaran yang harus ditempuh oleh peserta didik untuk memperoleh ijazah. Jadi ia dikatakan sebagai pengakuan formal dari suatu lembaga pendidikan (formal) bahwa yang bersangkutan telah menyelesaikan masa studi di lembaga tersebut.

Implikasi dari deskripsi tersebut jelas bahwa kurikulum terdiri dari sejumlah mata pelajaran; membentuk peserta didik menjadi manusia intelektual; pengajaran berarti penyampaian kebudayaan kepada generasi muda; tujuan kurkulum adalah untuk memperoleh ijazah; keharusan bagi peserta didik untuk mempelajari mata pelajaran yang sama; dan sistem penyampaian adalah sistem penuangan (Hamalik, 1993).

Adapun dalam pandangan modern, kurikulum bukan hanya sekedar kumpulan mata pelajaran yang harus diberikan dan dipelajari peserta didik, namun cakupannya lebih luas sehingga memasuki wilayah-wilayah pembelajaran di luar kelas. Maka implikasi dari kosep tersebut adalah: kurikulum tidak hanya terdiri mata pelajaran, akan tetapi meliputi semua kegiatan dan pengalaman; tidak ada pemisah antara intra dan ekstra kurikulum; bisa dilaksanakan baik di luar maupun di dalam kelas; pendidik perlu menggunakan berbagai kegiatan belajar mengajar secara bervariasi; dan tujuan pendidikan adalah membentuk pribadi dan belajar cara hidup (Idi, 1999).

Ada enam prinsip yang melekat pada kurikulum agar kurikulum berhasil sebagaimana mestinya, yakni: pertama, prinsip relevansi; menyangkut persoalan kebermaknaan apa yang disajikan kurikulum itu dengan kehidupan peserta didik. Prinsip ini setidaknya ada empat hal: relevansi pendidikan dengan lingkungan; relevansi pendidikan dengan kehidupan sekarang dan akan datang; relevansi pendidikan dengan dunia kerja; dan relevansi pendidikan dengan ilmu pengetuan (Subandijah, 1993). Kedua, prinsip efektivitas; menegaskan kurikulum harus didesain dengan memperhatikan kemampuan dan kondisi yang ada dengan cermat sehingga apa saja yang direncanakan dalam kurikulum dapat dicapai dengan baik.

Ketiga, prinsip efiesiensi; menegaskan usaha, biaya, waktu dan tenaga yang digunakan untuk menyelesaikan program diupayakan memiliki hasil yang seoptimal mungkin atau seimbang. Keempat, prinsip kesinambungan; bahwa kurikulum itu disusun secara gradual dan saling terkait antara satu jenjang pendidikan dengan jenjang pendidikan yang lain, antara satu topik materi dengan topik materi yang lain. Kelima, prinsip fleksibilitas; mengharapkan agar kurikulum disusun dengan memberikan ruang gerak yang luas bagi pelaksananya di lapangan sehingga dapat diterapkan dalam berbagai kondisi lingkungan. Keenam, prinsip berorientasi pada tujuan; bahwa semua 


\section{Faridi}

yang dituangkan dalam kurikulum didasarkan pada tujuan tertentu, sehingga semua yang direncanakan dalam proses pendidikan memiliki arah yang sudah jelas.

Secara umum kurikulum mata kuliah AIK diarahkan untuk menguasai, menghayati dan mengaplikasikan ajaran Islam ke dalam kehidupan nyata. Artinya, mahasiswa yang menerima mata kuliah tersebut diharapkan mereka mendapatkan dasardasar keterampilan keagamaan sebagai modal dan bekal mereka melksanakan dakwah di masyarakat. Serta memperoleh gambaran untuk mengembangkan wacana keilmuan dan mendapatkan dasar-dasar moral bagi kehidpan sehari-hari. Seperti dimaklumi bersama bahwa prioritas utama yang ingin dicapai oleh lembaga pendidikan Muhammadiyah dapat digambarkan sebagai berikut: jiwa tauhid yang murni; beribadah hanya kepada Allah; berbakti kepada orang tua serta bersikap baik terhadap kerabat; memiliki akhlaq yang mulia; berpengetahua luas serta memiliki kecakapan; dan ia berguna bagi masyarakat, bangsa dan agama. Atas dasar tesebut yang menjadi tolok ukur keberhasilan mata kuliah AIK yang paling pokok adalah terletak perubahan sikap, mental dan tingkah laku mahasiswa. Untuk mewujudkan hal tersebut, maka setiap lembaga pendidikan Muhammadiyah diwajibkan memasukkan mata kuliah AIK sebagai bagian integral dari kulikulum dengan harapan dapat mempengaruhi karakter para peserta didik baik selama proses pendidikan berlangsung terlebih setelah mereka keluar/lulus.

Hal tersebut selaras dengan visi misi Muhammadiyah. Sejak ia didirikan oleh K.H.A. Dahlan telah berkomitmen dengan perjuangan yang berorientasi pada: upaya menegakkan keyakinan Tauhid yang murni sesuai dengan al-Qur'an dan Sunnah Rasul. Membersihkan amalan Islam dari tradisi dan kepercayaan yang bersumber dari selain al-Qur'an dan Sunnah Rasul; menyebarluaskan ajaran Islam yang bersumber pada alQur'an dan Sunnah Rasul dengan sistem pendidikan modern; mewujudkan amalanamalan Islam dalam kehidupan perorangan keluarga, dan masyarakat sesuai dengan alQur'an dan Sunnah Rasul; dan mereformulasi doktrin Islam dengan pandangan alam modern.

Karenanya, ketika melihat sistem sekolah yang didirikan Belanda (masa penjajahan) para murid tidak diperkenalkan sama sekali bersentuhan dengan pendidikan Islam. KHA. Dahlan beserta beberapa tokoh Muhammadiyah bertekad untuk memperbaharui pendidikan bagi umat Islam. Pembaharuan yang dimaksud meliputi dua segi, yaitu: cita-cita dan segi teknik. Dari segi cita-cita adalah untuk membemntuk manusia Muslim yang berakhlaqul karimah, alim dalam beragam, luas pandanangan dan faham terhadap masalah keduniaan, cakap, bersedia berjuang untuk kemajuan agama Islam dan masyarakat. Oleh karenanya, target yang hendak dicapai oleh setiap lulusan pendidikan Muhammadiyah meliputi akidah yang benar, akhlaq yang mulia, cerdas, terampil dan siap mengabdi demi kepentingan agama Islam dan masyarakat. Sedang dari segi teknik adalah lebih banyak berhubungan dengan cara-cara penyelengaraan pendidikan modern terutama sistem yang diterapkan selama pelaksanaan pendidikan.

Terhadap sistem pendidikan model pesantren, Muhammadiyah berusaha mengubahnya dari bentuk lama dengan memperkenalkan sistem organisasi dan 
administrasi serta cara-cara penyelenggaraannya. Maka pada tahun 1920 Muhammadiyah mendirikan "Pondok Muhammadiyah", suatu perguruan tingkat menengah pertama kali di Yogyakarta yang memberikan pelajaran ilmu agama dan ilmu umu bersama-sama. Pada perkembangan berikutnya tepatnya tahun 1924, perguruan tersebut berubah menjadi "Kweekschool Muhammadiyah" dan dipecah menjadi dua bagian, yaitu: "Kweekschool Muhammadiyah Putri" (kini dikenal Madrasah Muallimat Muhammadiyah) dan "Kweekschool Muhammadiyah Putra" (dikenal Madrasah Muallimin Muhammadiyah).

Sedang bentuk kedua, seperti sekolah-sekolah sekuler yang didirikan oleh kolonial Belanda, Muhammadiyah menyelenggarakan sekolah-sekolah sejenis (sistem klasikal) dengan menambahkan mata pelajaran agama ke dalam kurikulumnya. Maka, pada tahun 1926 Muhammadiyah mendirikan "HIS med de Qur'an" yang kemudian berganti nama dengan "HIS Muhammadiyah". Kemudian dilanjutkan dengan mendirikan "MULO" 'HIK Muhammadiyah" dan "Schakel Scool Muhammadiyah". Adapun materi agama yang diajarkan sekitar 10-15 persen dari total kurikulum sekolahsekolah umum.

Usaha Muhammadiyah dengan mendirikan dan menyelenggarakan sistem pendidikan modern tersebut juga terintegrasi dengan ajaran Islam (sesuai dengan alQur'an dan as-Sunnah). Sehingga nantinya semua subjek pendidikan akan mampu memposisikan Islam menjadi rahmatan lil-alamin, petunjuk dan rahmat bagi kehidupan segenap umat manusia. Maka ciri khas lembaga pendidikan Muhammadiyah yang tetap dipertahankan sampai saat ini adalah dimasukkannya mata kuliah AIK di semua lembaga pendidikan tinggi milik Muhammadiyah. Wajar apabila pada Muktamar Muhammadiyah di Surabaya (tahun 1978) mencantumkan agar mata kuliah AIK akan mempengaruhi karakter para pelajar baik secara prosesual maupun keluarannya.

\section{Pembelajaran AIK dalam Persepsi}

Orientasi pembaharuan termasuk dalam bidang menjadi prioritas utama yang ingin dicapai oleh Muhammadiyah. Hal ini tergambar dari tujuan pendidikan Muhammadiyah, untuk mencetak peserta didik/lulusan sekolah Muhammadiyah, yaitu: memiliki jiwa tauhid yang murni; beribadah hanya kepada Allah; berbakti kepada orang tua serta bersikap baik terhadap kerabat; memiliki akhlaq yang mulia; berpengetahuan luas serta memiliki kecakapan; dan berguna bagi masyarakat, bangsa dan agama. Untuk mewujudkan hal ini, maka setiap lembaga pendidikan Muhammadiyah diwajibkan memasukkan mata kuliah AIK sebagai bagian integral dari kulikulum dengan harapan dapat mempengaruhi karakter para peserta didik baik selama proses pendidikan berlangsung terlebih setelah mereka keluar/lulus.

Sebagai bagian dari kurikulum, maka mata kuliah AIK merupakan salah satu mata kuliah (wajib) yang harus ditempuh oleh setiap mahasiswa. Namun melihat latar belakang pendidikan dan ideologi keberagamaan mahasiswa, dipandang perlu untuk 


\section{Faridi}

diketahui bagaimana sebenarnya persepsi mahasiswa terhadap mata kuliah tersebut. Berikut ini beberapa tanggapan mahasiswa:

"Menurut hemat saya, mata kuliah AIK perlu diberikan kepada mahasiswa, dikarenakan kehadiran UMM tidak lepas dari cita-cita Kemuhammadiyhan. Oleh karena itu, mahasiswa perlu diberi pemahaman terhadap perjuangan Muhammadiyah khususnya dalam bidang pendidikan. Di samping itu untuk mewujudkan kecintaan mahasiswa terhadap almamater UMM serta untuk memperkaya khazanah pengetahuan mahasiswa terhadap wawasan keislaman demi mewujudkan suasana indah dalam perbedaan dalam keberagamaan”.

"Mata kuliah AIK perlu diberikan kepada mahasiswa, terlebih UMM merupakan salah satu lembaga pendidikan formal yang dimiliki oleh persyarikatan sebagai sarana da'wah amar makruf nahil munkar'.

Dewasa ini, mulai dari Sambang sampai Merauke telah berdiri ranting, cabang, daerah hingga wilayah yang berlabel Muhammadiyah. Muhammadiyah ikut serta meningkatkan kualitas umat Islam atau bangsa Indonesia secara umum. Berbagai lembaga telah didirikan, di antaranya rumah sakit, rumah panti asuhan anak yatim dan orang tua lanjut usia, taman kanak-kanak, sekolah dasar, sekolah lanjutan tingkat pertama, sekolah lanjutan tingkat atas sampai perguruan tinggi. Bahkan dalam hal lembaga pendidikan, Muhammadiyah menduduki peringkat dua besar setelah pendidikan yang dikelola oleh pemerintah.

Hal tersebut memang sesuai dengan apa yang menjadi cita-cita pendiri Muhammadiyah yang termaktub dalam Anggaran Dasar Muhammaduyah Pasal 3 yakni: menegakkan dan menjunjung tinggi agama Islam, sehingga terwujud masyarakat utama, adil dan makmur yang diridhai oleh Allah. Terlebih lagi secara teoritik, ada tiga alasan mengapa mata kuliah AIK perlu diajarkan: mempelajari Kemuhammadiyahan yang pada dasarnya untuk mempelajari sebagian bangsa Indonesia yang beragama Islam dan mempunyai alam pikiran modern; memperkenalkan alam pikiran tersebut diharapkan mahasiswa dapat tersentuh dan sekaligus mengamalkannya; dan perlunya etis mahasiswa yang menempuh pendidikan di lembaga pendidikan Muhammadiyah.

Jelasnya secara praksis, tujuan-tujuan tersebut dapat dipahami oleh mahasiswa yang kritis terhadap pengetahuan diri atas keberagamaannya. Salah satunya menjelaskan bahwa:

"Mata kuliah AIK perlu diberikan kepada mahasiswa, tujuannya agar mahasiswa mengetahui asal usul atau sejarah berdirinya Muhammadiyah serta seluk beluk organisasi ini. Terlebih setelah lulus nantinya mahasiswa akan terjun ke masyarakat di mana di dalam masyarakat terdapat banyak organisasi-organisasi keislaman. Nah, dengan bekal AIK mahasiswa menjadi lebih paham antara organisasi Islam yang murni dan yang tidak murni”.

Terlebih lagi, selama ini terdapat kesalahpahaman sebagian masyarakat terhadap Muhammadiyah. Mereka menganggap Muhammadiyah-lah yang harus bertanggungjawab terhadap perpecahan berlarut-larut di kalangan umat Islam. Sebab 
dengan berdirinya Muhammadiyah umat Islam menjadi terkotak-kotak dan sulit dipersatukan. Mereka tidak mengetahui sejarah sebenarnya yang telah terjadi pada bangsa Indonesia yang menyebabkan lama terpuruk dalam genggaman penjajah dan telah menyebabkan umat Islam tertinggal dalam semua bidang. Dalam konteks kesejarahan, berdirinya Muhammadiyah merupakan tuntutan dan keharusan sejararah agar umat Islam memiliki jati diri dan daya tawar yang tinggi di mata penjajah. Muhammadiyah sebenarnya didorong oleh kegelisahan dan keprihatinan yang mendalam terhadap model dakwah dan pola pemikiran keagamaan konvensionaltradisional saat itu.

Dalam doktrin Islam disebutkan "kuntunkhaira ummah", namun kenyataannya hampir seluruh bangsa yang moyoritas penduduknya beragama Islam hidup dalam tekanan penjajah. Oleh karena itu, berdirinya Muhammadiyah antara lain dikarenakan: pertama, kondisi intern umat Islam yang masih tercengram fenoemena sinkritisme. Dan kedua, kondisi ekstern umat Islam, seperti atas kebijakan politik kolonial Belanda terhadap umat Islam dan/atau pengaruh perkembangan Islam di Timur Tengah. Fenomena itulah yang juga mendorong Muhammadiyah melakukan pembaharuan terhadap pendidikan. Atas upaya tersebut, maka pendidikan Muhammadiyah diorientasikan pada upaya: membersihkan Islam di Indonesia dari pengaruh dan kebiasaan yang bukan Islam; reformulasi doktrin Islam dengan pandangan alam pikiran modern; reformasi ajaran Islam dan pendidikan Islam; dan mempertahankan Islam dari pengaruh dan serangan luar Islam.

Dalam pandangan KHA. Dahlan sendiri, lembaga pendidikan agama yang ada di Indonesia seperti pondok pesantren tidak dapat mengikuti dan memenuhi tuntutan zaman; sementara pendidikan yang diselenggarakan kolonial Belanda sama sekali tidak memperhatikan pendidikan Islam. Perbandingan inilah yang menunjukkan substansi pembaharuan pendidikan Muhammadiyah. Fokus utama upaya reformasi ini adalah ingin meningkatkan sumberdaya manusia (SDM) umat Islam secara menyeluruh. Berdasarkan tujuan ideal pendidikan Muhammadiyah, maka mahasiswa memberikan penyataan bahwa:

"Tentu saja perlu, meskipun mahasiswa yang belajar di UMM bukan hanya mereka yang berlatar belakang Muhammadiyah, tetapi mereka perlu diberi pemahaman bahwa tempat mereka menuntut ilmu adalah buah karya sekaligus cita-cita organisasi Islam bernama Muhammadiyah. Di samping itu, mereka diharapkan memahami sesungguhnya lembaga pendidikan yang didirikan oleh Muhammadiyah tidak hanya dikhususkan kepada pengikut Muhammadiyah saja melainkan bagi seluruh umat lainnya; untuk yang beragama Islam, atau juga untuk mereka yang beragama non Islam. Bagi saya, mata kuliah ini cukuk menarik, karena saya menjadi paham apa sebenarnya tujuan didirikannya Muhammadiyah oleh KH. Ahmad Dahlan, mengapa organisasi ini lebih diterima oleh masyarakat kelas menengah ke atas dibending dengan masyarakat kelas menengah ke bawah". 
"Mata kuliah AIK perlu diberikan kepada seluruh mahasiswa Universitas Muhammadiyah Malang. Meskipun mata kuliah ini hanya wajib diketahui oleh penganut Muhammadiyah, namun bagi non Muhammadiyah tidak ada salahnya untuk diketahui sebagai tambahan pengetahuan sejarah tentang khazanah keislaman yang ada di Indonesia, dengan demikian dapat memberi penyadaran tehadap mahasiswa tentang pentingnya hidup toleran dan menerima perbedaan yang ada".

"Mata kuliah AIK sangat perlu diberikan kepada Mahasiswa UMM, sebab AIK ini dapat membuat mahasiswa mengetahui dan memahami misi, visi dan ideologi Muhammadiyah, memahami ajaran ajaran Islam yang murni sesuai dengan tuntunan al-Qur'an dan Hadis shahih".

Dengan demikian, mahasiswa mampu memahami garis besar misi dan visi Muhammadiyah. Pengetahuan mahasiswa terkait dengan visi dan misi serta orientasi Muhammadiyah dapat dipetakan sesuai dengan pola pembelajaran AIK. Visi dan misi yang mereka pahami, antara lain: menegakkan keyakinan tauhid yang murni sesuai dengan al-Qur'an dan as-Sunnah; menyebarkan ajaran Islam yang bersumber pada alQur'an dan as-Sunnah dengan sistem pendidikan modern; mewujudkan amalan-amalan Islam dalam kehidupan perorangan, keluarga maupun masyarakat; dan reformulasi doktrin Islam dengan alam pikiran modern.

Dengan demikian, mahasiswa lebih akrab terhadap ajaran Islam yang dibawa oleh Muhammadiyah. Mahasiswa pada aspek tertentu yakin jika sebagai gerakan Islam, Muhammadiyah bukan sekadar organisasi semata, melainkan juga sebagai gerakan keagamaan yang di dalamnya terkandung sistem keyakinan; pengetahuan organisasi; praktik aktifitas yang mengarah pada tujuan yang dicita-citakan. Dan mereka juga memahami bahwa Muhammadiyah sebagai organisasi dan/atau gerakan sangat memerlukan perekat yang kuat guna mempertahankan nilai-nilai, sejarah, ikatan dan kesinambungan gerakan dalam melaksanakan amal usaha. Karenanya, mahasiswa sangat memaklumi jika nilai-nilai ideologis keislaman terus ditanamkan.

Akhirnya mahasiswa juga memahami ideologi Muhammadiyah secara substansi terkandung di dalam muqaddimah anggaran dasar Muhammadiyah serta matan keyakinan dan cita-cita Muhammadiyah. Mereka juga mengetahui kalau fungsi ideologi dalam Muhammadiyah memiliki aspek-aspek tertentu, yaitu: memberi arah tentang paham Islam yang diyakini Muhammadiyah; mengikat solidaritas kolektif antar warga Muhammadiyah; membangun kesamaan dalam menyusun strategi perjuangan; membangun karakter warga Muhammadiyah; dan sarana memobilisasi anggota Muhammadiyah

Mahasiswa juga memahami kalau garis besar ideologi Muhammadiyah terdiri atas beberapa hal, yaitu: pertama, hidup manusia harus berdasar tauhid; ber-Tuhan, beribadah serta tunduk dan taat hanya kepada Allah. Kepercayaan tauhid mempunyai tiga aspek: kepercayaan dan keyakinan bahwa hanya Allah yang kuasa mencipta, memelihara, mengatur dan menguasai alam semesta; kepercayaan dan keyakinan bahwa hanya Allah Tuhan yang hak; dan kepercayaan dan keyakinan bahwa hanya Allah yang 
berhak dan wajib dihambai atau disembah. Kedua, hidup manusia itu bermasyarakat, maka harus senantiasa memberi nilai positif kepada masyarakat; ketiga, hanya hukum Allah yang sebenarya dijadikan sendi untuk membentuk pribadi utama dan mengatur ketertiban hidup bersama untuk menuju hidup bahagia, sejahtera di dunia dan akhirat. Keempat, berjuang menegakkan dan menjunjung tinggi agama Islam untuk mewujudkan masyarakat Islam yang sebenar-benarnya; kelima, perjuangan menegakkan dan menjunjung tinggi agama Islam akan berhasil bila mengikuti (ittiba') perjuangan Rasullah; keenam, perjuangan mewujudkan pokok pikiran tersebut hanya akan berhasil bila dilakukan dengan berorganisasi yang baik. Maka organisasi merupakan satusatunya alat/cara perjuangan yang sebaik-baiknya; dan ketujuh, kewajiban mengamalkan perintah Allah dan mengikuti sunnah Rasul guna mendapat karunia dan ridha-Nya baik di dunia maupun di akhirat nanti serta untuk mencapai masyarakat yang sentosa/bahagia disertai nikmat dan rahmat Allah yang melimpah.

Berdasarkan pengajaran pembelajaran AIK tersebut, mahasiswa juga mampu mengurai tata kelola keorganisasian Muhammadiyah. Oleh karena itulah, AIK dipersepsikan oleh mahasiswa sebagai keorganisasian yang modern sesuai dengan kaidah-kaidah manajemen modern. Beberapa orang mahasiswa kepada peneliti menyatakan bahwa:

"Mata kuliah AIK perlu diberikan agar mahasiswa mengetahui organisasi sosial keagamaan yang tulus ikhlas mengabdi kepada masyarakat, moderat dan tidak ekstrim, tidak radikal".

"Perlu diberikan, karena selain tuntutan akademik atau kurikulum, mata kuliah AIK juga dapat menambah pengetahuan agar mahasiswa kelak setelah lulus tidak mengalami kesalahpahaman dalam beragama yang dapat menimbulkan ketegangan dan perepcahan di kalangan umat Islam. Bagi saya, AIK merupakan hal yang baru dan tidak pernah saya terima selama ini. Dulu saya menganggap Muhammadiyah merupakan organisasi yang menyimpang, ternyata setelah mendapat penjelasan justru sebaliknya. Saya yang salah menilai Muhammadiyah, jadi menurut saya Kemuhammadiyahan perlu diberikan kepada semua mahasiswa UMM".

"Menurut saya perlu, agar mahasiswa mengerti tentang apa sebenarnya Muhammadiyah itu, karena mata kuliah AIK selain indentitas dan landasan ideal dari setiap sekolah atau lembaga yang didirikan oleh Muhammadiyah juga Muhammadiyah dapat menjadi organisasi alternatif bagi mahahasiswa kelak setelah lulus, agar perjuangan mereka mendapatkan wadah atau tempat sesuai dengan ajaran Islam yang murni".

Mahasiswa juga sadar jika saat ini masyarakat mengalami transformasi sosial. Gerak dinamis dan mobilitas mesyarakat yang tinggi menuntut tidak saja partisipasi masyarakat secara lebih aktif dan kreatif. Akan tetapi, juga menuntut berbagai gerakan sosial keagamaan seperti Muhammadiyah untuk secara lincah dan cerdas memberi arah 


\section{Faridi}

moralitas masyarakat. Tuntutan demikian, disadari oleh mahasiswa hanya mungkin dilakukan organisasi keagamaan yang mapan. Ternyata Muhammadiyah mampu membebaskan diri dari jebakan rutinitas parsial berbagai amal (aktivitas) sosialnya. Dalam kerangka ini pendekatan paradigmatik pemikiran dan amal KHA. Dahlan menjadi penting dan mendesak. Mahasiswa menyadari jika paradigma intelektual akan menjadi hakikat gerakan sosial yang sangat urgen. Bahkan bisa saja ia akan menjadi reison d'etre dinamisitas fungsional gerakan di tengah peradaban modern. Penempatan ide intelektual KHA. Dahlan sebagai paradigma merupakan masalah aktual ketika pembangunan bangsa telah memasuki era industrialisasi.

"Bagi mahasiswa yang memang berlatar belakang Muhammadiyah lebih mengerti secara mendalam tentang AIK, sedang bagi mereka yang bukan berlatar belakang Muhammadiyah menjadi paham tentang apa yang selama ini dan akan diperjuangkan oleh Muhammadiyah. Mereka yang kurang suka bahkan membenci Muhammadiyah bisa menjadi menyukai atau juga kalau bisa pindah menjadi pengikut Muhammadiyah".

"Ia bisa mengupayakan tiap individu mahasiswa menjadi pribadi yang muttaqin, yakni manusia yang bertanggung jawab untuk meneruskan ajaran Rasulullah. Selain itu mata kuliah AIK dapat menambah wawasan mahasiswa tentang organsasi keislaman serta memberi pemahaman kepada mahasiswa bahwa Muhammadiyah merupakan gerakan Islam modern yang berupaya untuk mengembalikan kemurnian Islam dari pengaruh-pengaruh ajaran yang sesat dengan berlandaskan pada al-Qur'an dan Hadits Rasul".

"Mengingat mahasiswa UMM tidak semuanya yang berasal dari lingkungan atau anggota Muhammadiyah, maka dengan diberikannya mata kuliah ini diharapakan mahasiswa memiliki pemahaman tantang ajaran AIK. Terlebih dalam materi AIK dapat dijadikan rujukan dan landasan tentang kehidupan yang sebenarnya, yakni kehidupan yang sesuai dengan ajaran al-Qur'an dan Hadits Rasulullah. Disamping itu, mahasiswa menjadi tahu akan sejarah berdirinya organisasi yang didirikan oleh KHA. Dahlan ini. Mahasiswa juga akan mengetahuai tentang tujuan berdirinya Muhammadiyah”.

Mahasiswa juga memberikan penilaian kritis bahwa beberapa pandangan strategis Muhammadiyah yang bersifat konstans dan sampai sekarang masih tetap relevan. Jika dipetakan pandangan-pandangan tersebut terdiri atas aspek: Pertama, Keyakinan bahwa Islam sebagai agama wahyu memberikan nilai-nilai dasar bagi para pemeluknya untuk mencapai kebahagiaan di dunia dan akhirat. Oleh karena nilai-nilai Islam adalah kongkruen atau sama dan sebangun dengan nilai-nilai kemanusian, maka perjuangan Muhammadiyah pada hakekatnya juga merupakan perjuangan kemanusiaan. Kedua, patriotisme dan nasionalime (wathaniyah dan qaumiyyah) adalah juga ajaran Islam, akan kedua hal itu tidak boleh jatuh menjadi xenophobisme sehingga dapat menimbulkan kebencian terhadap bangsa lain. Jadi sejak lahirnya Muhammadiyah memang berpaham kebangsaan dengan menghormati bangsa-bangsa lain. 
Ketiga; Muhammadiyah meletakkan pembangunan manusia sebagai salah satu strategi dasarnya. Oleh karena itu, tidak mengherankan bahwa bidang pendidikan sejak dari TK sampai Perguruan Tinggi, sejak dari Madrasah sampai Institut keagaman menjadi garapan pokok gerakan Muhammadiyah. Keempat, Muhammadiyah tidak pernah ingin berpolitik praktis. Para founding fathers Muhammadiyah di samping KHA. Dahlan sendiri sudah jauh-jauh hari membaca bahwa keterlibatan politik bagi Muhammadiyah dapat mengalihkan alur persyarikatan Islam reformis ke dalam jebakan-jebakan yang dapat merugukan persyarikatan ini. Dan kelima; dalam usaha mencapai tujuan dakwahnya (di bidang pendidikan, sosial, kesehatan, kepemudaan, kewanitaan, bahkan kehidupan ekonomi umat) Muhammadiyah berusaha untuk beswadaya dan beswasembada. Muhammadiyah tidak akan pernah mau menerima sumbangan atau bantuan apapun bila sampai ada indikasi yang akan mempengaruhi kemandirian dan kebebannya (freedom of action).

Bagaimana dengan model pembelajaran AIK yang pernah mereka tempuh? Menurut respoden, alangkah baiknya jika pembelajar AIK tidak menekankan pada "keilmuan semata" atau Islam sebagai disiplin ilmu. Akan tetapi, AIK juga diupayakan untuk menekankan pada Islam sebagai nilai. Alasan mahasiswa yang menempuh AIK tidak ingin menjadi kiyai/ustad, melainkan ingin menjadi pekerja profesional sesuai dengan pilihan fakultas masing-masing. Pada konteks inilah salah seorang mahasiswa menyampaikan bahwa:

"Pembelajaran AIK sangat monoton, terlalu menekankan pada aspek kognitif atau hafalan dan kurang mendorong terbangunnya penjiwaan nilai-nilai keseharian. Dengan kata lain, pembelajaran AIK kurang membangun kepribadian yang utuh".

Fenomena umum yang selama ini dirasakan oleh banyak kalangan antara lain yaitu penekanan kognitif. Bahkan memang kelemahan pendidikan agama dilembaga pendidikan formal penyampaian materi yang bersifat monoton dan banyak menyentuh aspek-aspek metafisika yang bersifat abstrak. Terkadang juga menyangkut hal-hal yang bersifat supra rasional, penyampaian materi yang terjebak pada indoktrinasi serta metode ceramah yang satu arah dan cenrderung membosankan peserta didik. Ketika diajukan pertanyaan sistem atau metode pembelajaran AIK serta sarana maupun prasarana penunjang pelaksanaan pembelajaran AIK menjawab sebagai berikut:

"Pengajaran AIK disampaikan dengan metode ceramah. Para dosen banyak yang tidak menguasai metode-motode modern yang dapat menghindari kebosanan mahasiswa terhadap pembelajaran AIK. Pembelajaran AIK akan lebih menarik jika ditunjang dengan sarana modern seperti multimedia".

Dalam ilmu kependidikan, mendidik diperlukan seni (teori) tersendiri agar peserta didik tidak jenuh, serta mudah menangkap materi. Hal tersebut perlu diperhatikan, karena salah satu penyebab kegagalan dalam proses belajar mengajar 


\section{Faridi}

antara lain minimnya kemampuan pendidik (dosen) dalam menguasai seni mengajar. Seni (teori) yang ada perlu disesuaikan dengan tingkat, kondisi, lokasi dan budaya peserta didik. Adapun jenis teori pembelajaran AIK sendiri yang diterapkan para dosen, antara lain sebagai berikut: Ceramah, Tanya jawab, Diskusi, Pemberian tugas/Rasitasi, Demontrasi \& eksperimin, Kerja Kelompok, Sosiodrama \& Bermai Peran, Karya Wisata, Driil/Latihan Siap, Sistem Regu/Team Teaching. Pada perjalanannya metode pembalajaran mengalami perbaikan dan melahirkan beberapa metode seperti: NonDirective, Intedisilinaritas, Inquiri, Istiqomah, Quantum Learning, Teaching Learning, Contextual Learning, Active Learning, Cooperative Learning, Game, dan lain-lain.

Dalam klaisifikasi metodologi pembelajaran, metode ceramah termasuk metode tradisional yang seringkali digunakan dalam pembelajaran AIK. Metode ini bukan berarti tidak layak untuk diterapkan, mahasiswa yakin jika metode ini selain memiliki kekurangan akan tetapi juka memiliki kebaikan. Adapun kebaikan-kebaikan metode ini menurut beberapa mahasiswa, antara lain: materi untuk orang banyak, pendidik memiliki kemampuan orasi, materi yang akan disajikan jumlahnya banyak, materi sebatas penjelasan, materi dapat disajikan dengan singkat, orgasasi kelas dapat disederhanakan, dan pendidik mudah menguasai kelas. Walaupun di sisi yang lain ada kekurang-kekurangan dari metode ceramah seperti sulit memantau pemahaman peserta didik tentang materi yang telah disampiakan, hanya mengejar target, peserta didik pasif, menimbulkan kebosanan.

Hasil pendidikan dengan metode tradisional (metode ceramah) yang pernah diterapkan justru mengembangkan kemampuan para mahasiswa. Namun, juga ada sebagian mahasiswa yang sangat kritis menilai metode pengajaran tradisional seperti metode ceramah dinilai gagal. Alasan mahasiswa, antara lain: mengabaikan keterlibatan penuh peserta didik; kerjasama peserta didik tidak tebangun; monoton atai tidak variasi dalam pembelajaran; dan motivasi internal tidak tumbuh. Oleh karenanya, para dosen AIK berusaha untuk mengumpulkan informasi secara aktif dalam menciptakan pembelajaran yang lebih komprehensif. Salah satu upaya, munculnya pembelajaran yang bernuansa pengembangan pengetahuan mahasiswa secara aktif dan konstruktivisme. Orientasinya juga untuk membentuk lingkungan belajar yang aktif untuk mahasiswa; agar ia mengalami (mendapat pengalaman) pembelajaran secara mental, fisik, maupun sosial. Oleh karena itu, selama proses belajar mengajar berlangsung hal-hal yang diperhatikan para dosen AIK adalah: lingkungan belajar (lingkungan fisik, emosional, dan sosial) dibangun secara positif; suasana yang menggugah semangat, minat, kegembiraan dan rasa aman; mahasiswa diibatkan secara penuh dan aktif serta mengambil tanggung jawab penuh atas usaha belajarnya sendiri; pengetahuan tidak diserap secara pasif oleh mahasiswa melainkan diciptakan (dikonstruk) secara aktif oleh peserta didik; belajar yang berfokus pada aktivitas daripada materi atau presentasi; ada kerjasama di antara mahasiswa dalam suatu komunitas belajar; meminimalisir persaingan dan meningkatkan kerjasama; menggunakan berbagai metode mengajar; mahasiswa diharapkan menggunakan semua 
inderanya sesuai dengan kebutuhan; dan mahasiswa diharapkan melibatkan pikiran dan tubuhnya.

\section{Simpulan}

Dari hasil pembahasan dalam riset ini dapat disimpulkan bahwa semua responden menyetujui mata kuliah AIK diberikan kepada mahasiswa Unversitas Muhammadiyah Malang dengan berbagai alasan, antara lain mata kuliah AIK perlu diberikan kepada mahasiswa, karena kehadiran UMM tidak lepas dari cita-cita Kemuhammadiyhanitu sendiri oleh karena itu mahasiswa perlu diberi pemahaman terhadap perjuangan Muhammadiyah khususnya dalam bidang pendidikan, di samping itu untuk mewujudkan kecintaan mahasiswa terhadap almamater (UMM) serta untuk memperkaya khazanah mahasiswa terhadap wawasan keislaman demi mewujudkan suasana indah dalam perbedaan dalam keberagamaan.

Mata kuliah AIK perlu diberikan, karena selain menjadi ciri khas dari perguruan atau lembaga pendidikan yang ada dilingkungan Muhammadiyah. AIK juga diharapkan mampu untuk membekali mahasiswa mempunyai pengetahuan keislaman yang kuat, memahami arti perjuangan Muhammadiyah, toleran, dan bahkan mahasiswa tidak membenci Muhammadiyah yang selama ini banyak dipahami secara keliru di masyarakat. Bahkan di sisi yang lain, mata kuliah AIK perlu diberikan agar mahasiswa memiliki pengetahuan dan pemahaman tentang memahami Islam secara murni, serta dapat mengamalkan nilai-nilai Islam dalam kehidupan yang sebanarnya dan membentuk pribadi Muslim yang bertanggung jawab terhadap Allah dan masyarakat secara umum.

Berdasarkan harapan ideal tersebut, pembelajaran AIK perlu mengurai kedinamisasiannya. Hal ini agar mahasiswa menjadi kader militan, handal dan berkualitas unggul, tangguh dan bertanggung jawab terhadap organiasi Muhammadiyah. Sebab pembelajaran AIK oleh mahasiswa dinilai monoton, terlalu menekankan pada aspek kognitif atau hafalan dan kurang mendorong terbangunnya penjiwaan nilai-nilai keseharian. Selain itu, metode pembelajaran AIK, sarana maupun prasarana perlu pembenahan-pembenahan agar mahasiswa terhindar dari kejenuhan.

\section{DAFTAR PUSTAKA}

Al-Qur'an dan Tarjamahnya, 2000, Depag, Jakarta

Abdurrahman, Muslim, 2003, Islam Sebuah Kritik, Erlangga, Jakarta

Ali, Mukti, 1991, Memahami Beberapa Aspek Ajaran Islam, Mizan, Bandung

Arifin, MT.,1990, Muhammadiyah Potret yang Berubah, Institut Gelagang Pemikiran, Surakarta

Basyir, Azhar, 1994, Refleksi Atas Persoalan Keislaman, Mizan, Bandung

Dien, Syamsuddin (editor), 1990, Muhammadiyah, Kini dan Esok, Pustaka Panjimas, Jakarta 
Faridi

Ghazali, Abd. Rohim, dkk., 2007, Muhammadiyah Progresif (Manifesto Pemikiran Kaum Muda), JIMM-LESFI, Yogyakarta

Hambali, Hamdan, 2007, Ideologi dan Strategi Muhammadiyah, SuaraMuhammadiyah, Yogyakarta

Kuntowijoyo, 2001, Muslim Tanpa Masjid, Mizan, Bandung

Ma'arie, Syafi'i, 1995, Membumikan Islam, Pustaka Pelajar, Yogyakarta

Mu'ti, Abdul dan Fajar Riza'ul Haq, 2009, Kristen Muhammadiyah (Konvergensi Muslim dan Kristen dalam Pendidikan), Al-Wasat, Jakarta

Mulkhan, Munir, 2007, Pesan dan Kesan Kiai Ahmad Dahlan dalam Hikmah Muhammadiyah, Suara Muhammadiyah, Yogyakarta

Sucipto, Hery, 2005, Tajdid Muhammadiyah dari Ahmad Dahlan hingga Syafi'i Ma'arief, Grafindo, Jakarta

Sihab, Alwi, 1998, Muhammadiyah Membendung Arus, Mizan, Bandung 